\title{
誘電緩和法によるヘマトクリットをパラメータとした赤血球の特性周波数と 血栓形成過程の計測
}

\author{
朝倉 悠太 ${ }^{* 1}$ ，サプコタ アチュタ*2，丸山 修*3 \\ 小阪 亮*3, 山根 隆志 ${ }^{* 4}$, 武居 昌宏*1
}

\section{Measurement of characteristic frequency of red blood cells and thrombogenic process for various hematocrit values using dielectric relaxation method}

\author{
Yuta ASAKURA $^{* 1}$, Achyut SAPKOTA ${ }^{* 2}$, Osamu MARUYAMA ${ }^{* 3}$ \\ Ryo KOSAKA ${ }^{* 3}$, Takashi YAMANE ${ }^{* 4}$ and Masahiro TAKEI ${ }^{* 1}$ \\ ${ }^{* 1,{ }^{2} 2}$ Division of Artificial Systems Science, Graduate Course of Mechanical Engineering, Chiba University \\ 1-33 Yayoi, Inage-ku, Chiba 263-8522, Japan \\ ${ }^{* 3}$ National Institute of Advanced Industrial Science and Technology \\ 1-2-1 Namiki, Tsukuba-shi, Ibaraki 305-8564, Japan \\ ${ }^{*}$ Department of Mechanical Engineering, Graduate school of Engineering, Kobe University \\ 1-1 Rokkodai, Nada-ku, Kobe-shi, Hyogo 657-8501, Japan
}

Received 20 January 2014

\begin{abstract}
Dielectric relaxation method has been proposed for the possibility of real-time detection of thrombosis by exploiting the electrical properties of the blood. In-vitro experiments were conducted with bovine blood to measure relative permittivity and dielectric loss in the case of various hematocrit values under static blood condition. As a result, the relaxation frequency of the electrode and red blood cells were observed at $20 \mathrm{kHz}$ and $2 \mathrm{MHz}$ respectively. The characteristics frequency showing the permittivity of the red blood cells membrane was in the range of $60 \mathrm{kHz}$ to $1 \mathrm{MHz}$. The time variations of resistivity and relative permittivity were observed at this frequency range of characteristics frequency of red blood cell membrane. Resistivity and relative permittivity measured at this frequency range increased in the case of the increase in the hematocrit values. Additionally, a peak was observed in the temporal change in relative permittivity only in the case of that frequency range. Moreover, from the results of visual check of thrombosis, this peak indicated the start of the micro-thrombus formation. This phenomenon was specific to the thrombosis, and was observed only in the presence of red blood cells. The experiments showed the possibility of the real time detection of thrombosis for implantable ventricular assistance devices, heart-lung machines and artificial kidney.
\end{abstract}

Key words : Dielectric relaxation method, Relaxation frequency, Thrombus formation, Red blood cell, Artificial heart

\section{1. 緒言}

現在，体内植込み型補助人工心臓をはじめとして，人工心肺，人工腎臓などの人工藏器が開発され，害用化に 至っている(Yamane, 2000). しかしながら，その実用化において血栓の形成が最大の問題点となっており，従来ま で，血栓形成のセンシングとシミュレーションに関する研究が多くなされている．例えば，光を用いたセンシン グ技術では，玉川らは，CFD(Computational Fluid Dynamics)を用いて活性化したフィブリノーゲンによる血栓生成 予測のシミュレーション(Tamagawa, et al. 2009)を行い，レーザの散乱光量を用いて，血栓濃度分布を計測し，せ

No.14-00033 [DOI: 10.1299/transjsme.2014bms0245]

*1 正員, 千葉大学大学院工学研究科（广263-8522 千葉県千葉市稲毛区弥生町 1-33）

*2 千葉大学大学院工学研究科

*3 正員, (独) 産業技術総合研究所（†305-8564 茨城県つくば市並木 1-2-1）

${ }^{* 4}$ 正員, フェロー, 神戸大学大学院工学研究科（一 $657-8501$ 兵庫県神戸市灘区六甲台町 1-1）

E-mail of corresponding author: sapkota@chiba-u.jp 
儿断速度と血栓生成メカニズムの関係を解明した(福島他，2007)。大島らは，レーザ光を用いて，光路長とエミ ッタディテクタ距離の最適化を行い，赤血球濃度を計測できるシステムを開発した(Oshima and Sankai, 2009). こ れらの光計測を血液流路断面の血栓可視化計測に用いた場合，低へマトクリット場においては有効であるが，一 般的なヒトのへマトクリットである 40\%程度(Lisbeth, et al., 2012)の高へマトクリット場においては, その非透過 性のため, 流路断面の血栓計測は難しい。一方，これらの光計測に対して，高へマトクリットでも測定可能な電 気計測に関する研究として, 佐々木らは, 電気インピーダンス計測により, 模擬循環回路, および, 動物実験に おいてポンプ内血流量と血液電気伝導率が高い相関を示すことを明らかにした(佐々木他, 1992). また，電気計 測を用いた血栓, および, 血栓形成過程の計測に関する研究として, Noshiro et al.は, 血液中の塞栓を二電極間で インピーダンス計測を行い，血液と凝固した血液では導電率に差が生じることを明らかにした(Noshiro, et al., 2007). Affanni et al.は, マイクロチャンネル内の流動血液中の血栓を誘電緩和法により計測し, 血栓が形成され ると時間的にインピーダンスが増加することを明らかにした(Affani, et al., 2012). Hayashi et al.は, 誘電緩和法を 用いて, 血栓形成過程と非凝固状態とを比較し, 血栓形成過程に特徵的なピークが現れることを明らかにした (Hayashi, et al., 2010). また，筆者らは，プロセス・トモグラフィー法を用いて，固定測定周波数で静止血液中に ミリオーダーの血栓を沈降させ, センサ断面で血栓の相対空間導電率の時間空間可視化計測に成功した(朝倉他, 2013). しかしながら，これらの既往研究では，交流測定周波数を掃引して計測を行ったとき，血栓がインピーダ ンスを増加させることは明らかになっているものの，ヘマトクリットが血栓形成過程の電気的特性に与える影響 は未だ明らかとなっていない.

そこで, 本研究では, 誘電緩和法を用いて, ヘマトクリットをパラメータとした非凝固状態(こてで, 非凝固状

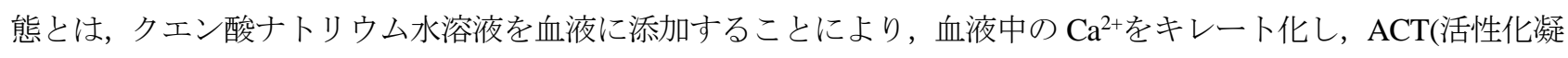
固時間)が 1000s 以上にすることで, 静止血液中において, 血液凝固過程が進行しない状態と定義する)において, 赤血球膜の特性周波数を明らかにし，その特性周波数を用いて，血栓形成過程において，比誘電率と抵抗率の時 間変化を計測し，さらに，ヘマトクリットをパラメータとした血栓形成過程の時間変化を計測し，血栓形成過程 においてへマトクリットが与える電気的特性の影響について検討することを目的とする.

\section{2. 実験装置 $\cdot$ 方法 $\cdot$ 条件}

\section{$2 \cdot 1$ 実験装置}

図 1(a)は実験装置であり，電極ホルダ，インピーダンスアナライザ(HIOKI IM3570)，および，制御用 PC から 構成されている．電極ホルダとインピーダンスアナライザとは，4 端子対構造を持つケーブルによって接続され ている，原点 $O$ は，電極ホルダの底面の一端を中心として，X, $Y$, および， $Z$ 軸を図の通りとった．ポリメタク リル酸メチル樹脂(PMMA)製の立方体容器の電極ホルダの内寸の一辺 $h_{\mathrm{s}}$ は $20 \mathrm{~mm}$, 厚さ $t_{\mathrm{h}}$ は $2 \mathrm{~mm}$ であり, $X=0 \mathrm{~mm}$, および, $X=20 \mathrm{~mm}$ の $Y-Z$ 平面に SUS304 製電極が配置されている. インピーダンスアナライザは, 1 プロットを $\Delta t=1.38 \mathrm{~ms}$ (測定周波数 $f=5 \mathrm{MHz}$ )から $8.2 \mathrm{~ms}$ (測定周波数 $f=1 \mathrm{kHz}$ ) で計測することができ，その測定周波数確度は $\pm 0.01 \%$ であり, 計測確度は $\pm 0.6 \%$ あるる. 制御用 PC は, インピーダンスアナライザから送信されたキャパシタ ンスやコンダクタンスのデータから比誘電率, および, 抵抗率を求めた。 図 1(b)は, 本実験装置により, 血栓形 成過程を計測している状況を示したものである.

\section{$2 \cdot 2$ 誘電緩和法と血液の電気的等価回路}

誘電緩和法とは，交流測定周波数を掃引して，レジスタンス，リアクタンス，キャパシタンス，および，コン ダクタンスなどの電気物理量を計測し，その周波数応答の違いから，細胞内部，細胞膜，および，溶液の比誘電 率, 誘電損失, 抵抗率などの電気特性量を求めることができる手法であり(山本, 中村, 2011), 細胞の電気特性 を調べることにも用いられている(Asami, 2002).

図 2 は，一般的な血液の等価回路を示したものである(山本，中村，2011).ここで， $R_{\mathrm{p}}$ は血漿のレジスタンス， $R_{\mathrm{i}}$ は赤血球のレジスタンス, $C_{\mathrm{m}}$ は赤血球の膜キャパシタンスを示す. 低測定周波数では, 赤血球膜のキャパシタ ンスに起因するリアクタンス $\left(X_{\mathrm{c}}=1 /\left(2 \pi f C_{\mathrm{m}}\right), f\right.$ は交流測定周波数 $)$ が血漿のレジスタンスと比較して大きいため, 
低測定周波数では，血漿のみに電流が流れる，一方，高測定周波数になるほど，赤血球膜のリアクタンス成分が 小さくなり，赤血球膜にも電流が流れ，等価回路全体に電流が流れる.

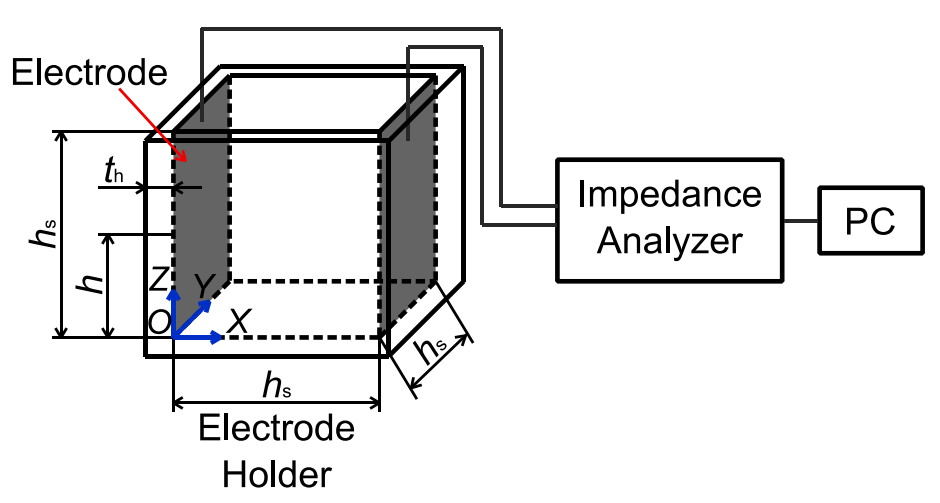

(a) Overview(inside dimension)

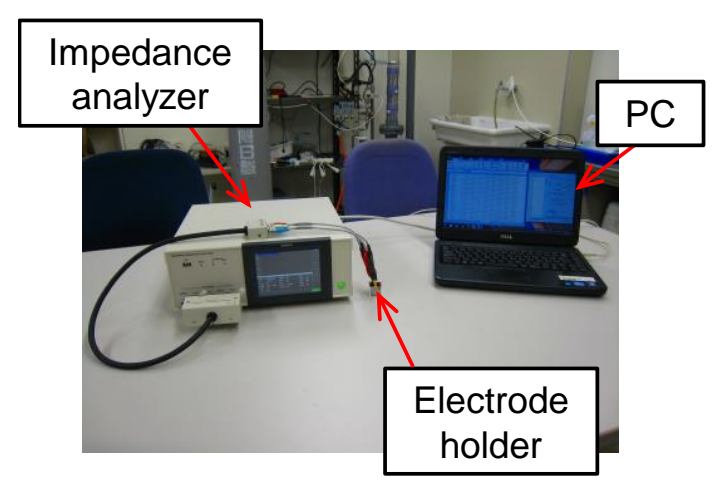

(b) Photograph of experiment

Fig.1 Experimental setup

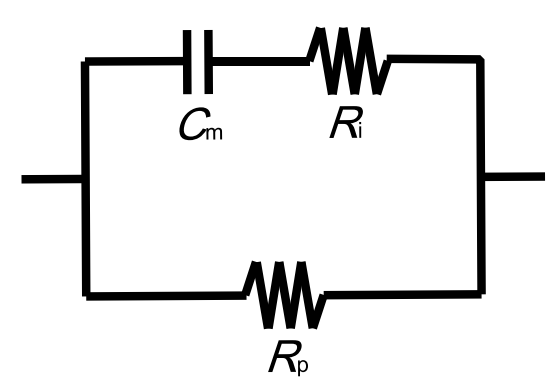

Fig.2 Electrical equivalent circuit of blood

\section{$2 \cdot 3$ 実験方法と実験条件}

\section{$2 \cdot 3 \cdot 1$ 電極ホルダの較正実験方法}

はじめに, 電極ホルダやケーブルなどに生じる浮遊容量 $C_{\mathrm{r}}$ を求めるために, 純水(MILLIPORE) $4.0 \mathrm{~mL}$ を電極ホ ルダの高さ $h=10.0 \mathrm{~mm}$ まで正確に入れ，その純水を用いたキャパシタンス $C_{\mathrm{w}}$ を計測した. 各測定周波数 $f$ にき 5 プロットの平均值をその $C_{\mathrm{w}}$ とした， $C_{\mathrm{r}}$ は,

$C_{r}=C_{w}-\varepsilon_{w} C_{0}$

で表し(Asami, 2002)，C $C_{0}$ はセル定数で，

$$
C_{0}=\varepsilon_{0} \frac{S_{e}}{h_{s}}
$$

である. ここで, 真空の誘電率 $\varepsilon_{0}=8.854 \times 10^{-12} \mathrm{~F} / \mathrm{m}$, 電極間距離 $h_{\mathrm{s}}=20.0 \times 10^{-3} \mathrm{~m}$, 純水の誘電率 $\varepsilon_{\mathrm{w}}=78.0 \mathrm{~F} / \mathrm{m}$ である. 本実験では, 純水は電極ホルダの高さの半分までしか充填されていないため, 空気の誘電率が残りの上部の電極 面積を占めることになる。しかしながら, 空気の誘電率 $\varepsilon_{\mathrm{a}}$ は $1.0 \mathrm{~F} / \mathrm{m}$ であり, 空気の誘電率 $\varepsilon_{\mathrm{a}}$ は純水の誘電率 $\varepsilon_{\mathrm{w}}$ と比較すると $\varepsilon_{\mathrm{a}}<<\varepsilon_{\mathrm{w}}$ であるので, 本実験での浮遊容量 $C_{\mathrm{r}}$ を算出する際の電極面積 $S_{\mathrm{e}}$ は, 純水の充填した高さ $h=10.0 \mathrm{~mm}$ と考えられるので $S_{\mathrm{e}}=2.0 \times 10^{-4} \mathrm{~m}^{2}$ となる. 以上の各值を式(2)に代入すると， $C_{0}$ は,

$$
C_{0}=8.854 \times 10^{-14} \mathrm{~F}
$$

となる.この較正実験において, 電極に印加した交流電流は $i=4.0 \mathrm{~mA}$ であり, 交流測定周波数 $f$ は $1 \mathrm{kHz}$ から $5 \mathrm{MHz}$ である. 


\section{$2 \cdot 3 \cdot 2$ 赤血球の特性周波数推定の実験方法と条件}

次に, 非凝固状態におけるへマトクリット $H$ をパラメータとした比誘電率 $\varepsilon$, 誘電損失 $\varepsilon$, および，抵抗率 $\rho$ の電気特性量を求めた. 東京芝浦臟器株式会社より購入したウシ全血をへマトクリット遠心分離器(KUBOTA セ ンテック 3220)で， 12000rpm かつ 5 分間遠心することにより， ウシ全血のへマトクリットを計測した. 表 1 に示 した通り， ウシ全血のへマトクリット $H=36 \%$ をとに $H=0 \%$ から $H=60 \%$ までの 8 種類のへマトクリットを調整 したウシ血液を作成した，非凝固状態におけるウシ全血，および， $H$ を調整したウシ血液には，血液 $4.0 \mathrm{~mL}$ に対 して，0.4mL のクエン酸ナトリウム水溶液に含まれるクエン酸によってキレート化し，自然に血栓形成すること を阻止した．これらの合計 8 種類のウシ血液 $4.0 \mathrm{~mL}$ をそれぞれ電極ホルダ内の高さ $h=10.0 \mathrm{~mm}$ まで充填し，血液 を充填後，キャパシタンス $C[\mathrm{~F}]$ ，および，コンダクタンス $G[\mathrm{~S}]$ の計測を行った．前述の較正実験と同様に各測定 周波数 $f$ につき 7 プロットの平均值をその $C$, および, $G$ とした．計測した $C$, および, $G$ の值から, 物質固有 の值である比誘電率 $\varepsilon$, 誘電損失 $\varepsilon "$, および, 抵抗率 $\rho$ を

$$
\begin{aligned}
\varepsilon^{\prime} & =\frac{C-C_{r}}{C_{0}} \\
\varepsilon^{\prime \prime} & =\frac{G}{2 \pi f C_{0}} \\
\rho & =\frac{C_{0}}{\varepsilon_{0} G}
\end{aligned}
$$

で表し(Park, et al., 2003)，横軸に $f$, 縦軸に $\varepsilon$ ，および， $\varepsilon$ ”グラフを作成することにより，そのピークを調べる ことで, 電極の緩和周波数 $f_{\mathrm{ec}}$, 赤血球膜の特性周波数 $f_{\mathrm{m}}$ ，および，赤血球の緩和周波数 $f_{\mathrm{rc}}$ を推定した．本実験に おいて, 電極に印加した交流電流 $i$ と, 掃引した交流測定周波数 $f$ の実験条件は, 前述の較正実験と同じである. Noshiro et al.は, ブタ血液に 10.0mA の交流電流を印加したときの血液の生化学的な影響は無視できるとしており (Noshiro, et al., 2007), 本実験でも, 4.0mA の交流電流を印加しても血液の生化学的な影響は無視できるとした.

Table 1 Experimental condition of hematocrit change

\begin{tabular}{|c|c|c|c|c|c|c|c|c|}
\hline & $H=0 \%$ & $H=10 \%$ & $H=20 \%$ & $H=30 \%$ & $H=36 \%$ & $H=40 \%$ & $H=50 \%$ & $H=60 \%$ \\
\hline Blood cells [mL] & 0.00 & 0.40 & 0.80 & 1.20 & 1.44 & 1.60 & 2.00 & 2.40 \\
\hline Plasma [mL] & 4.00 & 3.60 & 3.20 & 2.80 & 2.56 & 2.40 & 2.00 & 1.60 \\
\hline
\end{tabular}

\section{$2 \cdot 3 \cdot 3$ 血栓形成過程と非凝固状態の実験方法と条件}

その次に, 推定した $f_{\mathrm{ec}}, f_{\mathrm{m}}$, および, $f_{\mathrm{rc}}$ を用いて, $H=36 \%$ のシ全血の血栓形成過程における電気物理量の計 測を行った. 前述と同様に電極ホルダに $3.0 \mathrm{~mL}$ のウシ全血を静かに充填した後, 血栓形成を促進させるために, 2 種類の濃度の塩化カルシウム水溶液 $\left(\mathrm{CaCl}_{2}\right)$ を添加した。ここで, 本実験では, 血液には流動性はなく, 静止血 液中における血栓形成過程の電気特性について計測した。その 2 種類とは, $\mathrm{CaCl}_{2} 1.0 \mathrm{~mL}(0.02 \mathrm{M}$, Sysmex)(ウシ全 血 $3.0 \mathrm{~mL}$ に対して $25 \mathrm{vol} \%$ の水溶液) と, $\mathrm{CaCl}_{2} 0.6 \mathrm{~mL}$ (ウシ全血 $3.0 \mathrm{~mL}$ に対して $15 \mathrm{vol} \%$ の水溶液) と $\mathrm{PBS}$ (Phosphate Buffered Saline) $0.4 \mathrm{~mL}$ である. ここで, PBS を添加した理由として, $\mathrm{CaCl}_{2} 25 \%$ の水溶液と同じへマトクリットに するためである. また，本実験結果の妥当性について検討するために，ウシ全血を 5 検体用意し，それぞれウシ 全血 $3.0 \mathrm{~mL}$ に対して $\mathrm{CaCl}_{2} 1.0 \mathrm{~mL}(25 \mathrm{vol} \%)$ を添加した. さらに，以上のウシ全血における血栓形成過程に対して， 非凝固状態の時間変化を比較検討寸るために, ウシ全血 $3.0 \mathrm{~mL}$ に対して, PBS を $1.0 \mathrm{~mL}(25 \mathrm{vol} \%)$ 添加して $C$, お よび, $G$ の計測を行った. ここで, $\mathrm{CaCl}_{2}$ を添加した瞬間を $t=0.0 \mathrm{~min}$ とし, $t=60.0 \mathrm{~min}$ まで $C$ と $G$ の計測を行った. 本実験において, 電極に印加した $i$ と, 掃引した $f$ は, 前述の較正実験と同じである. また, 血栓形成過程の計 測において，いつ血栓が形成し始めたかを定性的に特定するために, 2.1 で示したものと全く同じ電極ホルダをも う 1 つ用意し, 前述と同様にウシ全血 $3.0 \mathrm{~mL}$ に $\mathrm{CaCl}_{2} 25 \mathrm{vol} \%$, および, $\mathrm{CaCl}_{2} 15 \mathrm{vol} \%$ を添加し, $t=2.5 \mathrm{~min}$ ごとに 血栓形成か非凝固状態かを血液の粘性，および，血栓の有無を目視で観察することで確認した，以上の血栓形成 過程，および，非凝固状態における $\varepsilon^{\prime}$, および, $\rho$ との比較検討を容易にするために, $t=0.0 \mathrm{~min}$ の比誘電率 $\varepsilon^{\prime}$ initial と抵抗率 $\rho_{\text {initial }}$ を用いて, $\varepsilon^{\prime}(t)$ と $\rho_{(t)}$ とを正規化し, 相対比誘電率 $\varepsilon^{\prime *}$ と相対抵抗率 $\rho *$ を 


$$
\begin{gathered}
\varepsilon^{\prime *}=\frac{\varepsilon_{(t)}^{\prime}}{\varepsilon_{\text {initial }}} \\
\rho^{*}=\frac{\rho_{(t)}}{\rho_{\text {initial }}}
\end{gathered}
$$

により求めた.

\section{$2 \cdot 3 \cdot 4$ ヘマトクリットをパラメータとした血栓形成過程の実験方法と条件}

最後に, 推定した $f_{\mathrm{m}}$ を用いて,ヘマトクリットを変化させ, 赤血球が血栓形成過程に及ぼす影響を調べた. $H=0 \%$ から 40\%まで $10 \%$ す変化させたウシ血液に対して，それぞれ $3.0 \mathrm{~mL}$ を電極ホルダに充填し， $\mathrm{CaCl}_{2}$ をれぞれ $1.0 \mathrm{~mL}$ 添加して計測を行った. ここで, $\mathrm{CaCl}_{2}$ を添加した瞬間を $t=0.0 \mathrm{~min}$ とし, $t=60.0 \mathrm{~min}$ まで $C$ の計測を行った. 本実験において，電極に印加した $i$ と，掃引した $f$ は，前述の較正実験と同じである.

\section{3. 実験結果}

\section{$3 \cdot 1$ 浮遊容量の算出}

図 3 は, 純水によるキャパシタンス $C_{\mathrm{w}}$ の 3 回のアンサンブル平均をとった計測結果である. この図に示した 通り，測定周波数 $f=1 \mathrm{kHz}$ から $5 \mathrm{MHz}$ の範囲で， $C_{\mathrm{w}}$ は $8.3 \mathrm{pF} \pm 0.2 \mathrm{pF}$ でほぼ一定值を示し，ほとんど計測誤差がな いことが分かる．したがって，本実験で電極ホルダの較正に用いる $f$ は，後述の電極分極の影響が少ない $100 \mathrm{kHz}$ を用い, そのときの $C_{\mathrm{w}}$ は, $8.33562 \mathrm{pF}$ であり, 浮遊容量 $C_{\mathrm{r}}$ は, 式(1)を用いて求めると, $C_{\mathrm{r}}=1.4295 \times 10^{-12} \mathrm{~F}$ となる.

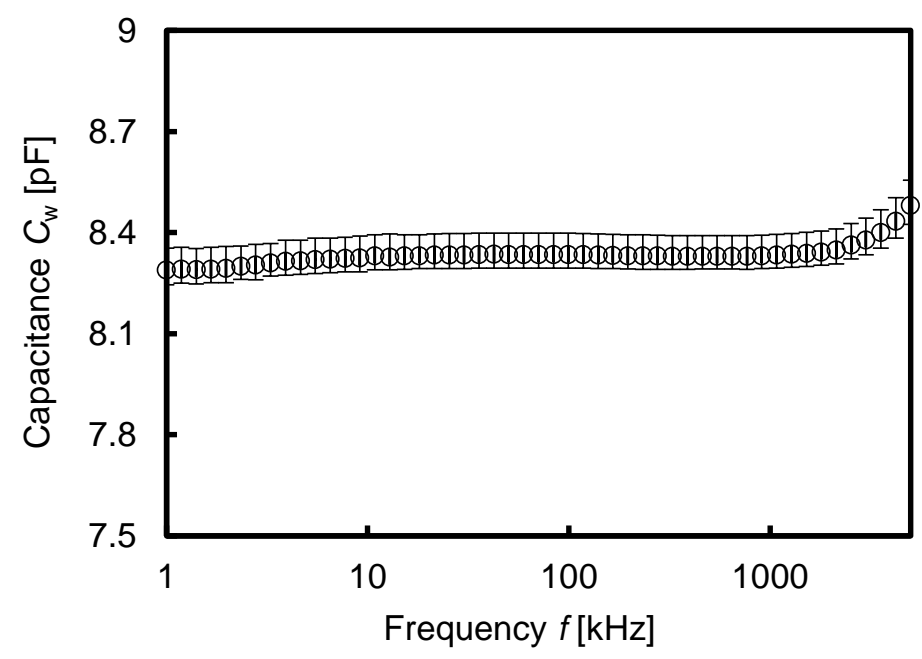

Fig.3 Result of capacitance measurement of pure water

\section{$3 \cdot 2$ 非凝固状態でヘマトクリットをパラメータとした電気特性量の計測結果}

図 4 は, ヘマトクリット $H$ をパラメータとした式(4)により求めた測定周波数 $f$ と比誘電率 $\varepsilon$ ' との関係を示した ものである.この図に示した通り，H=10\%から $60 \%$ におい, $f$ が約 $1 \mathrm{kHz}$ から $60 \mathrm{kHz}$ までは, $\varepsilon^{\prime}$ が直線的に減少 し, $f=60 \mathrm{kHz}$ から $1 \mathrm{MHz}$ までは， $\varepsilon^{\prime}$ はほぼ一定值として推移し， $f=1 \mathrm{MHz}$ 以上では， $\varepsilon^{\prime}$ 洅び咸少することが分か る. 本研究では, 赤血球膜の特性周波数 $f_{\mathrm{m}}$ の值を, $\varepsilon^{\prime} の 一$ 定值を示す $f=60 \mathrm{kHz}$ から $1 \mathrm{MHz}$ までのほぼ中間值であ る $f_{\mathrm{m}}=250 \mathrm{kHz}$ とする.

図 5 は， $H$ をパラメータとした式(5)により求めた $f$ と誘電損失 $\varepsilon ”$ との関係を示したものである. この図に示し た通り, すべての $H$ において, $f=20 \mathrm{kHz}$ で $\varepsilon$ ”ピークが現れ，その後， $H=10 \%$ 以上おおいて, $f=2 \mathrm{MHz}$ で再び $\varepsilon ”$ のピークが現れていることが分かる. 


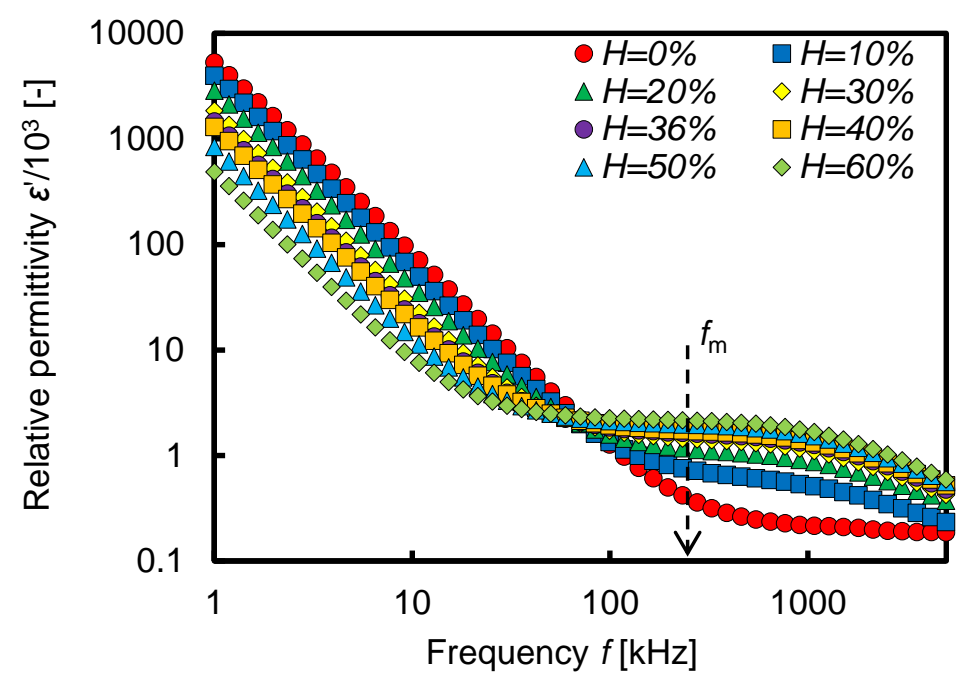

Fig.4 Relationship between frequency and relative permittivity in the case of various hematocrit values

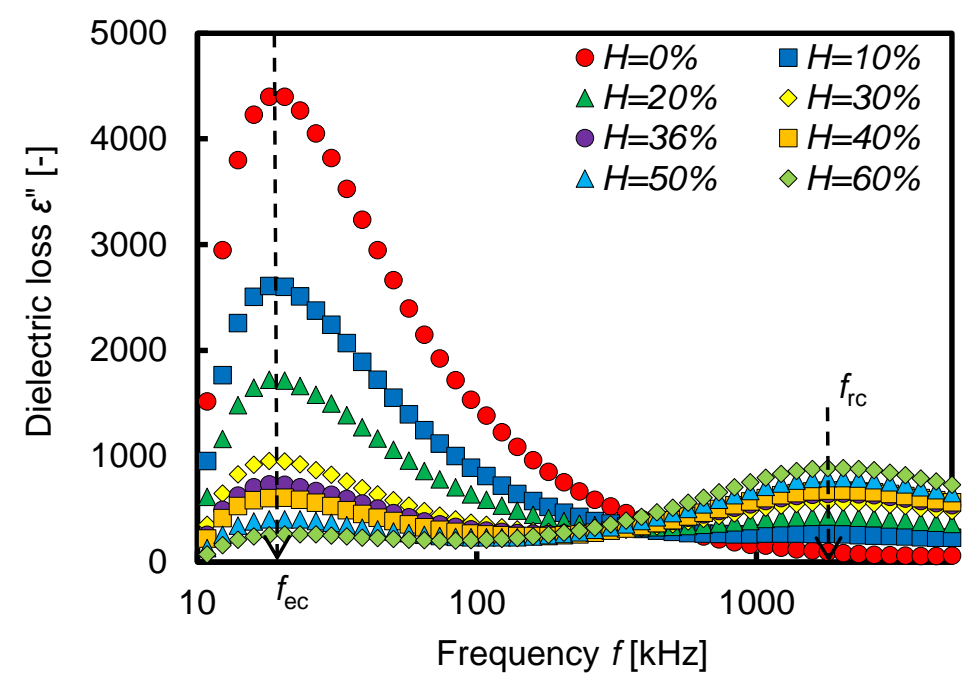

Fig.5 Relationship between frequency and dielectric loss in the case of various hematocrit values

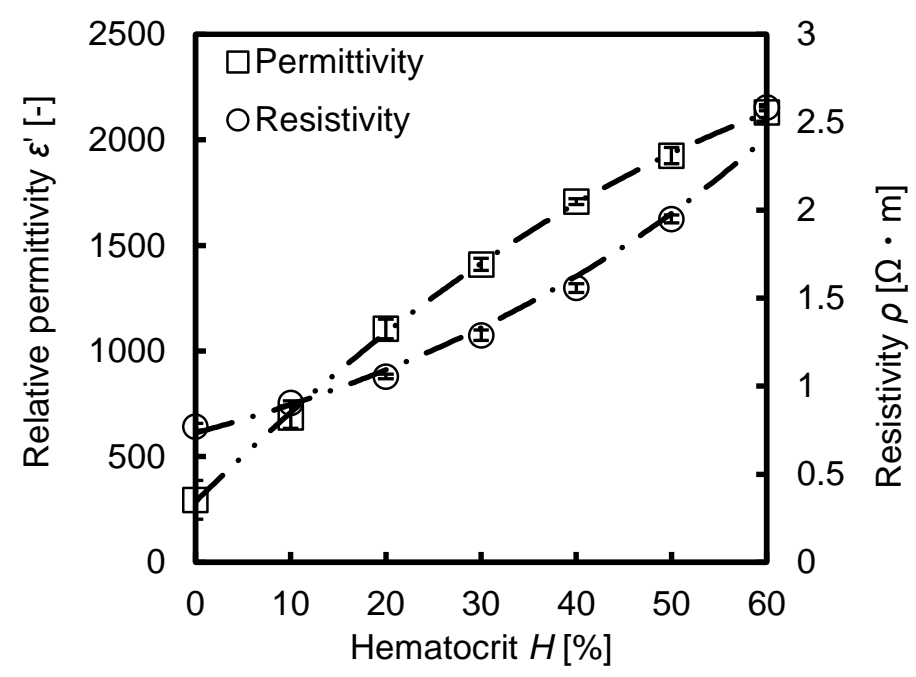

Fig.6 Relationship between hematocrit, relative permittivity and resistivity 
図 6 は 3 検体のアンサンブル平均をとった $H$ と $\varepsilon$, および, $H$ と抵抗率 $\rho$ との関係を示したものであり, 赤血 球膜の特性周波数 $f_{\mathrm{m}}=250 \mathrm{kHz}$ のときのキャパシタンス $C$, および, コンダクタンス $G$ の值から, 式(4)と式(6)を用 いて求めたものである.この図に示した通り, $\varepsilon^{\prime} は H$ が増加するにつれて,

$$
\varepsilon^{\prime}=-0.2345 H^{2}+44.416 H+286
$$

の近似式で表され，上に凸の二次曲線的に増加し， $\rho$ は $H$ が増加するにつれて，

$$
\rho=0.7345 e^{0.0198 H}
$$

の近似式で表され，指数関数的に増加することが分かる.

\section{$3 \cdot 3$ 全血の血栓形成過程と非凝固状態の計測結果}

図 7 は， $\mathrm{CaCl}_{2} 25 \mathrm{vol} \%$ を添加したウシ全血の血栓形成過程において，電極の緩和周波数 $f_{\mathrm{ec}}=20 \mathrm{kHz}$ ，赤血球膜の 特性周波数 $f_{\mathrm{m}}=250 \mathrm{kHz}$ ，および，赤血球の緩和周波数 $f_{\mathrm{rc}}=2 \mathrm{MHz}$ を用いて電気物理量を計測し，式(7)，および，式 (8)により求めた相対比誘電率 $\varepsilon^{\prime *}$, および, 相対抵抗率 $\rho *$ 時間変化である. この図に示した通り, $f_{\mathrm{ec}}$, および, $f_{\mathrm{rc}}$ における $\varepsilon^{\prime} *$ は, 時間経過につれて減少した。 しかしながら, $f_{\mathrm{m}}$ における $\varepsilon^{\prime *} *$ は, 時間経過につれて減少したが, $t=16.0 \mathrm{~min}$ をピークとして， $\varepsilon^{\prime} *$ *増加した．具体的には， $t=60.0 \mathrm{~min} の \varepsilon *$ *は $t=16.0 \mathrm{~min}$ の $\varepsilon^{\prime *}$ と比較して, 約 $1.6 \%$ 高い. また，すべての $f$ において， $\rho$ *は時間変化とともに多少の違いはあるものの，ほぼ同様の曲線を描いて増

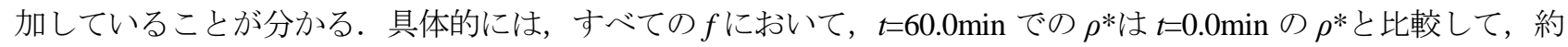
$3 \%$ 高く, 各測定周波数における $\rho$ *の特徵ある傾向は得られなかった. 表 2 は, $\mathrm{CaCl}_{2} 25 \mathrm{vol} \%$ を添加したウシ全血 の血栓形成過程を, 目視で確認した結果である.ここで, 一は非凝固状態, +は $1 \mathrm{~mm}$ 以下の目視で確認可能な $\mu \mathrm{m}$ サイズ血栓, +十は $1 \mathrm{~mm}$ 以上の $\mathrm{mm}$ サイズ血栓, +++ +電極ホルダ全体に広がった $\mathrm{cm}$ サイズ血栓を示寸. 図 8 は, 目視により確認した $\mu \mathrm{m}$ サイズ血栓, $\mathrm{mm}$ サイズ血栓, $\mathrm{cm}$ サイズ血栓の写真を示す.この表に示した通り, $t=10.0 \mathrm{~min}$ までは, 非凝固状態であり, $t=15.0 \mathrm{~min}$ で $\mu \mathrm{m}$ サイズ血栓が形成し始め, その後, 急激に血栓が形成さ

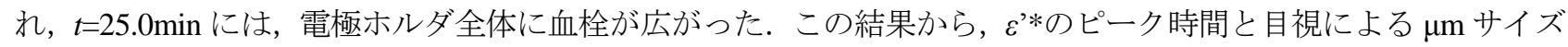
血栓形成の時間がほぼ一致していることが分かる。ここで， $\mu \mathrm{m}$ サイズ血栓が 1 個形成されたのみでは

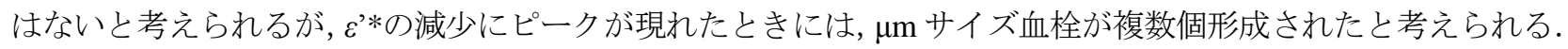

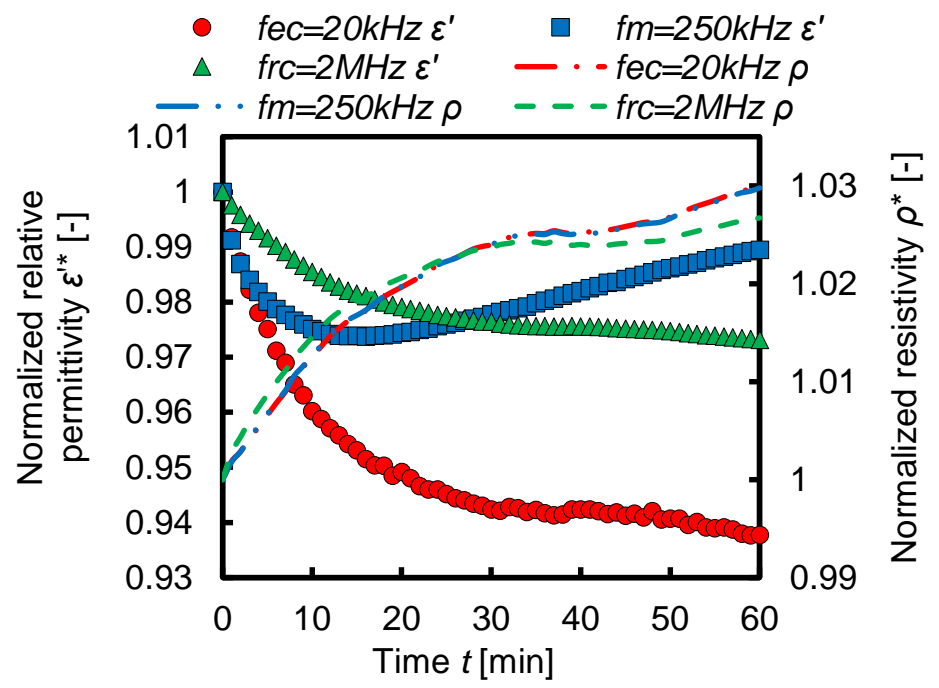

Fig.7 Normalized relative permittivity and normalized resistivity with time under thrombogenic condition by the addition of $25 \mathrm{vol} \%$ calcium chloride in whole blood

図 9 は, 5 検体のウシ全血に $\mathrm{CaCl}_{2} 25 \mathrm{vol} \%$ を添加したウシ全血の血栓形成過程において, $f_{\mathrm{m}}=250 \mathrm{kHz}$ を用いて電 気物理量を計測し, 式(7)により求めた $\varepsilon^{*} *$ 時間変化である. この図に示した通り, すべての検体において血栓

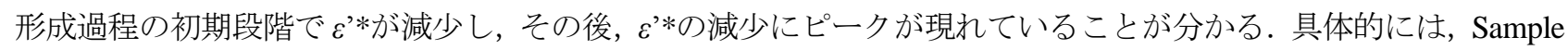
1 で $t=4.0 \mathrm{~min}$, Sample 2 で $t=8.2 \mathrm{~min}$, Sample 3 で $t=10.0 \mathrm{~min}$, Sample 4 で $t=8.8 \mathrm{~min}$, Sample 5 で $t=11.0 \mathrm{~min}$ であり, 
検体ごとにピーク時間や $\varepsilon *$ *值に多少の違いはあるものの, すべての検体で同様の傾向を確認することができた.

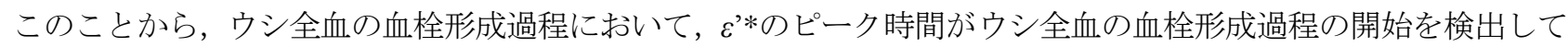
いると考えられ， $\rho^{*}$ より $f_{\mathrm{m}}=250 \mathrm{kHz}$ での $\varepsilon^{*} *$ 時間変化を調べることで, $\mu \mathrm{m}$ サイズ血栓の形成を検出できると 考えられる.

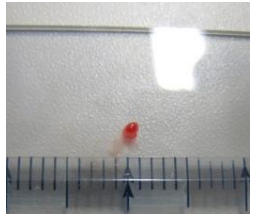

(a)

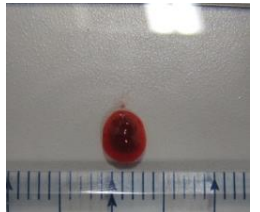

(b)

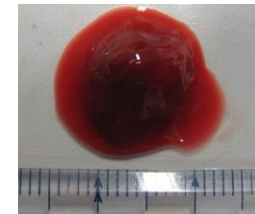

(c)

Fig.8 Photograph of thrombus size ((a): $\mu \mathrm{m}$ size thrombus, (b): mm size thrombus, (c): $\mathrm{cm}$ size thrombus)

Table 2 Result of visual check under thrombogenic condition by the addition of $25 \mathrm{vol} \%$ calcium chloride in whole blood

\begin{tabular}{|c|c|c|c|c|c|c|c|}
\hline Time $t[\mathrm{~min}]$ & 0.0 & 2.5 & 5.0 & 7.5 & 10.0 & 12.5 & 15.0 \\
\hline Visual check & - & - & - & - & - & - & + \\
\hline Time $t$ [min] & 17.5 & 20.0 & 22.5 & 25.0 & 27.5 & $\cdots$ & 60.0 \\
\hline Visual check & + & ++ & ++ & +++ & +++ & $\ldots$ & +++ \\
\hline
\end{tabular}

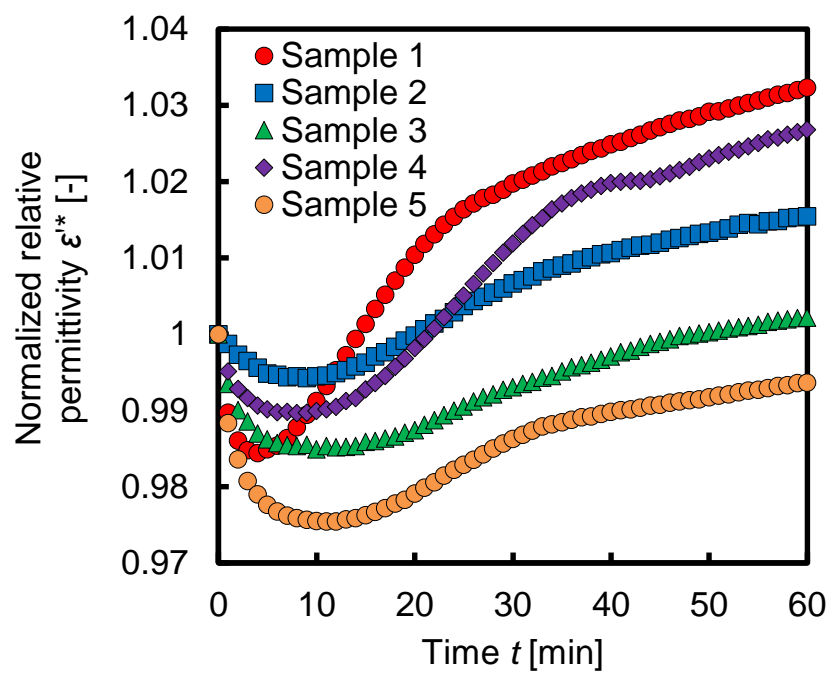

Fig.9 Normalized relative permittivity with time under thrombogenic condition by the addition of $25 \mathrm{vol} \%$ calcium chloride in 5 blood samples

図 10 は, $\mathrm{CaCl}_{2} 15 \mathrm{vol} \%$ を添加したウシ全血の血栓形成過程において, $f_{\mathrm{ec}}=20 \mathrm{kHz}, f_{\mathrm{m}}=250 \mathrm{kHz}$ ，および, $f_{\mathrm{rc}}=2 \mathrm{MHz}$ を用いて電気物理量を計測し，式(7)，および，式(8)により求めた $\varepsilon *$ ，および， $\rho^{*}$ の時間変化である。 この図に 示した通り, 前述の $\mathrm{CaCl}_{2} 25 \mathrm{vol} \%$ ときの血栓形成過程と同様に, $f_{\mathrm{m}}=250 \mathrm{kHz}$ において $\varepsilon^{\prime *}$ *が減少してから, $t=9.2 \mathrm{~min}$ をピークとして，増加に転じていることが分かる. 具体的には, $t=60.0 \mathrm{~min} の \varepsilon^{*} *$ は, $t=9.2 \mathrm{~min} の \varepsilon^{*}$ と比較して, 約 $2.9 \%$ 高い. しかしながら， $f_{\mathrm{ec}}=20 \mathrm{kHz}$ ，および， $f_{\mathrm{rc}}=2 \mathrm{MHz}$ では前述の $\mathrm{CaCl}_{2} 25 \mathrm{vol} \%$ を添加した時と同様に $\varepsilon^{\prime *}$ * 時間経過につれて，減少していることが分かる．また， $\rho^{*}$ に関しては，す心゙ての測定周波数において，多少の違 いはあるものの，ほぼ同様の曲線で増加していることが分かる．表 3 は, $\mathrm{CaCl}_{2} 15 \mathrm{vol} \%$ を添加したウシ全血の血 栓形成過程を, 目視で確認した結果である.この表に示した通り, $t=5.0 \mathrm{~min}$ までは, 非凝固状態であり, $t=10.0 \mathrm{~min}$ で $\mu \mathrm{m}$ サイズ血栓が形成し始め, $t=25.0 \mathrm{~min}$ には電極ホルダ全体に血栓が広がっている. この結果から, 前述の 
$\mathrm{CaCl}_{2} 25 \mathrm{vol} \%$ と同様に，\&*のピーク時間と目視による $\mu \mathrm{m}$ サイズ血栓形成の時間がほぼ一致していることが分か る.

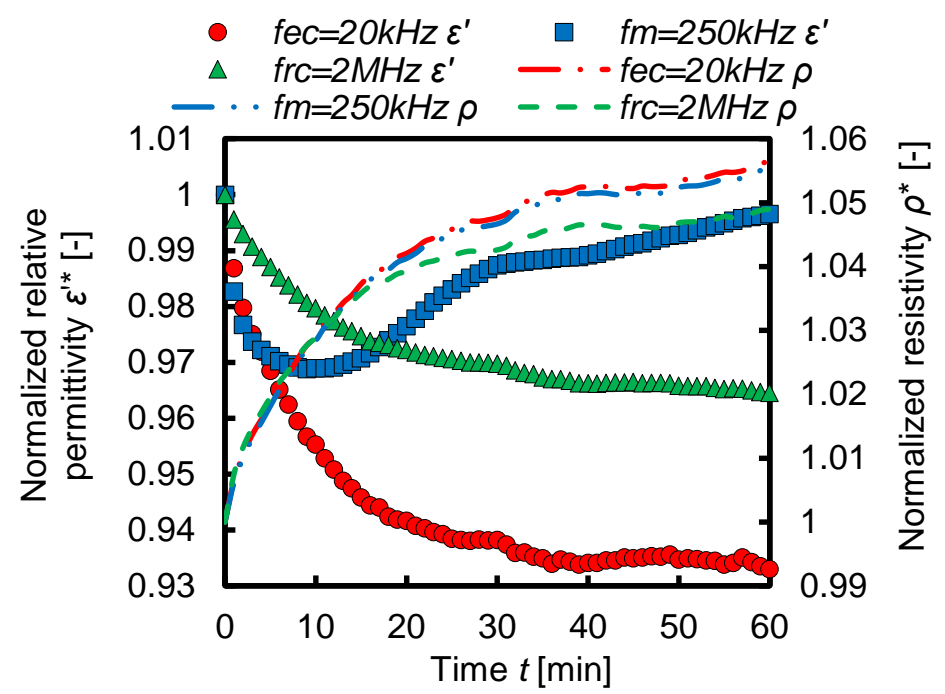

Fig.10 Normalized relative permittivity and normalized resistivity with time under thrombogenic condition by the addition of $15 \mathrm{vol} \%$ calcium chloride in whole blood

Table 3 Result of visual check under thrombogenic condition by the addition of $15 \mathrm{vol} \%$ calcium chloride in whole blood

\begin{tabular}{|c|c|c|c|c|c|c|c|}
\hline Time $t[\mathrm{~min}]$ & 0.0 & 2.5 & 5.0 & 7.5 & 10.0 & 12.5 & 15.0 \\
\hline Visual check & - & - & - & - & + & + & + \\
\hline Time $t[\mathrm{~min}]$ & 17.5 & 20.0 & 22.5 & 25.0 & 27.5 & $\cdots$ & 60.0 \\
\hline Visual check & + & ++ & ++ & +++ & +++ & $\ldots$ & +++ \\
\hline
\end{tabular}

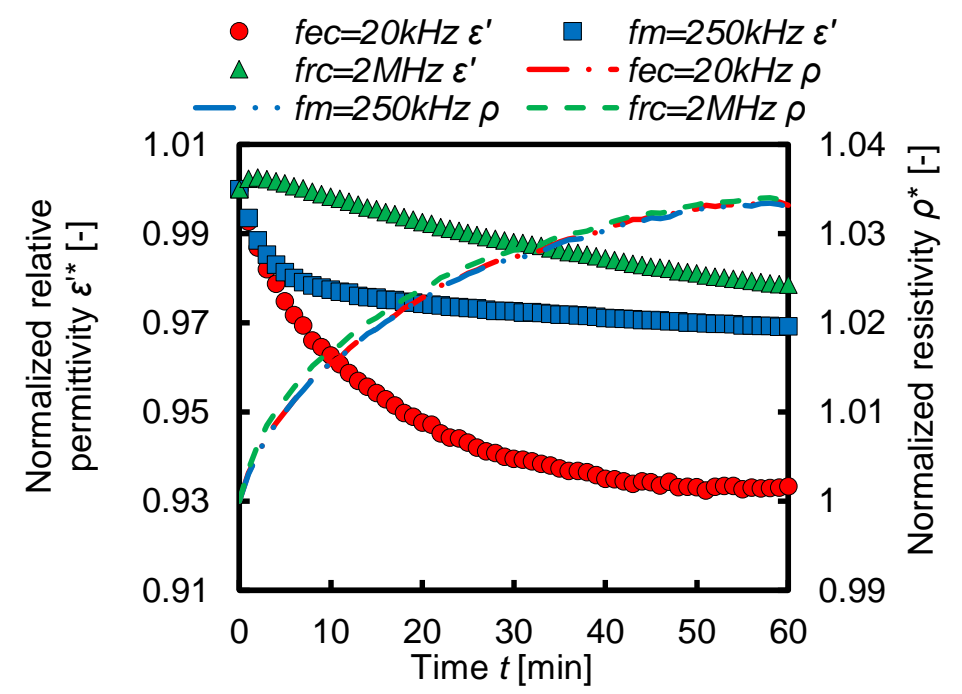

Fig.11 Normalized relative permittivity and normalized resistivity with time under non-thrombogenic condition by the addition of 25 vol\% PBS in whole blood

次に，非凝固状態において， $f_{\mathrm{ec}}=20 \mathrm{kHz}, f_{\mathrm{m}}=250 \mathrm{kHz}$ ，および， $f_{\mathrm{rc}}=2 \mathrm{MHz}$ における $\varepsilon^{\prime * と} \rho^{*}$ 時間変化を調べ，血 栓形成過程との違いについて考察する. 図 11 は, PBS 25vol\%を添加したウシ全血の非凝固状態において, 電気 物理量を計測し，式(7)，および，式(8)により求めた $\varepsilon *$ ，および， $\rho^{*} の$ 時間変化である. この図に示した通り， 
$f_{\mathrm{ec}}, f_{\mathrm{m}}$ ，および， $f_{\mathrm{rc}}$ のすべての測定周波数において， $\rho^{*}$ *時間経過とともに増加し，図 7, および，図 10 に示し た，血栓形成過程における $\rho^{*}$ と同様であり，血栓形成過程と非凝固状態における $\rho^{*} の$ 違いは区別できない.

\section{$3 \cdot 4$ ヘマトクリットをパラメータとした血栓形成過程での電気特性量の計測結果}

3.3 での血栓形成過程と非凝固状態における赤血球膜の特性周波数 $f_{\mathrm{m}}=250 \mathrm{kHz}$ の相対比誘電率 $\varepsilon^{\prime} *$ の時間変化の

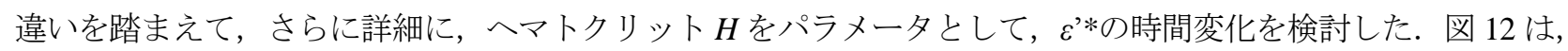
$H$ をパラメータとしたウシ血液の血栓形成過程を, $f_{\mathrm{m}}=250 \mathrm{kHz}$ を用いて電気物理量を計測し, 式(7)により求めた $\varepsilon *$ \%時間変化である. この図に示した通り， $H=0 \%$, 寸なわち, 血漿のみにおける血栓形成過程においては, 時 間経過につれて, $\varepsilon *$ *が減少し，ピークが現れないことが分かる. 具体的には, $t=60.0 \mathrm{~min} の \varepsilon * *, t=0.0 \mathrm{~min}$ のそ

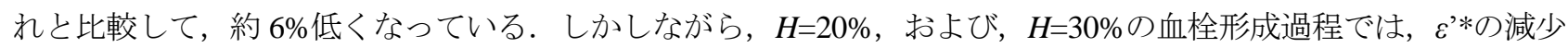
にピークが現れ, その後, 時間経過につれて, $\varepsilon^{*} * か ゙$ 増加する. 具体的には, $H=20 \%$ で $t=10.0 \mathrm{~min}, H=30.0 \%$ で $t=9.2 \mathrm{~min}$,

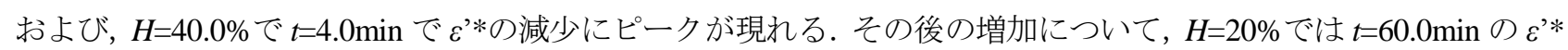
は $t=10.0 \mathrm{~min}$ の $\varepsilon^{*}$ と比較して, 約 $1.7 \%$ 高い. $H=30 \%$ では, $t=60.0 \mathrm{~min}$ の $\varepsilon^{\prime} *$ は, $t=9.2 \mathrm{~min}$ の $\varepsilon^{\prime *}$ と比較して, 約 $2.8 \%$ 高い. $H=40 \%$ では, $t=60.0 \min の \varepsilon^{*} *$ は, $t=4.0 \min の \varepsilon^{*}$ と比較して, 約 $4.9 \%$ 高い. また, $H=10 \%$ にいては, $H$, 寸なわち, 赤血球濃度が少ないため, $\varepsilon^{\prime} *$ 減少し続け, $t=45.0 \mathrm{~min}$ で減少のピークに達し, その後, 徐々に $\varepsilon^{*} * か ゙$ 増加していることが分かる.

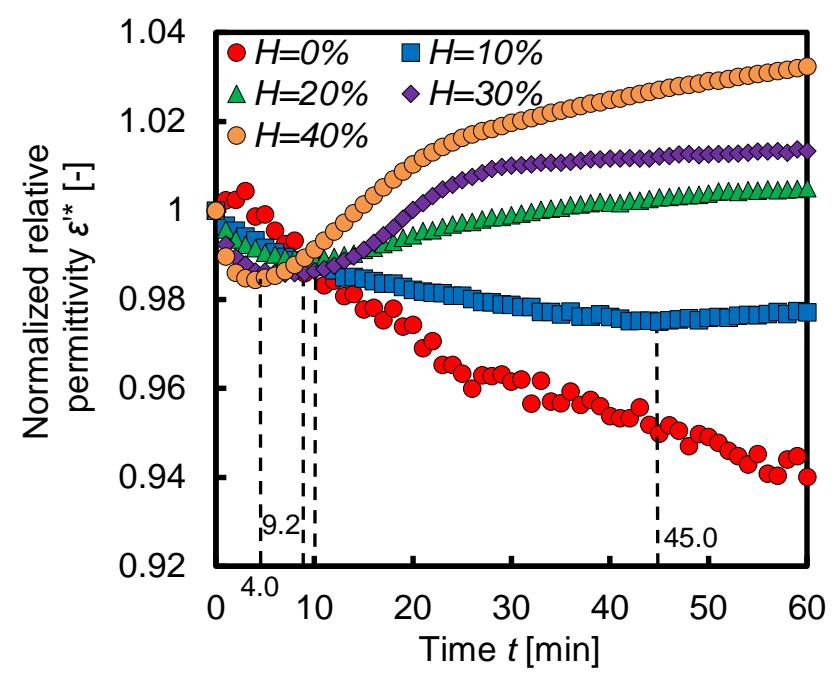

Fig.12 Hematocrit dependent temporal change in normalized relative permittivity under thrombogenic condition

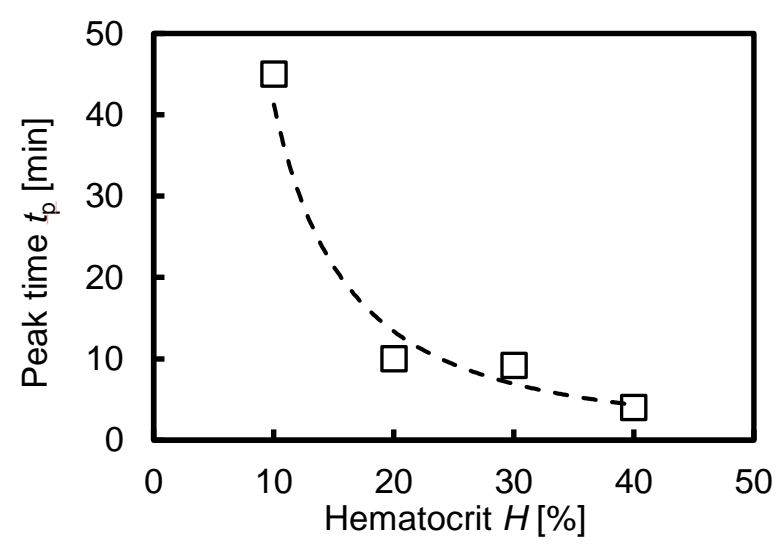

Fig.13 Relationship between hematocrit and peak time 


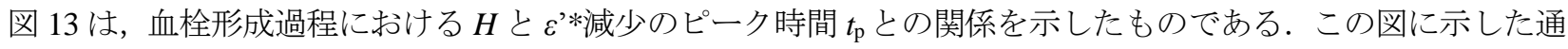
り, $H$ が増加すると, $t_{\mathrm{p}}$ は

$$
t_{p}=1743.5 H^{-1.626}
$$

で表され，累乗の関数で減少していること分かる.

\section{4. 考察}

\section{$4 \cdot 1$ 非凝固状態でヘマトクリットをパラメータとした電気特性量の考察}

図 3 における考察として, $f$ が約 $1 \mathrm{kHz}$ から $60 \mathrm{kHz}$ までの $\varepsilon^{\prime} の$ 減少は，電極分極の影響であることがすでに示さ れており(花井, 2000 ), $f=60 \mathrm{kHz}$ から $1 \mathrm{MHz}$ までの $\varepsilon^{\prime} の 一$ 定值は, 赤血球の誘電率, 寸なわち, 赤血球膜の特性周 波数 $f_{\mathrm{m}}$ を示し, $f=1 \mathrm{MHz}$ 以上の $\varepsilon^{\prime}$ の減少は, 赤血球の誘電緩和を示している. しかしながら, $H=0 \% の$ 血漿のみの 場合には, 赤血球が $f=60 \mathrm{kHz}$ を超えても一定值として推移せず, 急激に減少し続け, その後一定值となり, $H=10 \%$ 以上における $f=60 \mathrm{kHz}$ から $5 \mathrm{MHz}$ までの反応は，赤血球の存在によるものであると思われる，次に，図 4 におけ る考察として，この 2 つのピークは，前述の図 4 の結果である $f=20 \mathrm{kHz}$ が電極分極の影響を示寸周波数帯である ことから，電極の緩和周波数 $f_{\mathrm{ec}}$ を示している．また， $f=2 \mathrm{MHz}$ においては，赤血球の誘電緩和を示寸周波数帯で

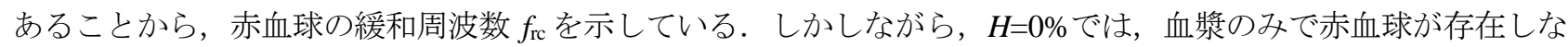
いため, $f_{\mathrm{ec}}=20 \mathrm{kHz}$ で電極の緩和周波数が現れた後, $f_{\mathrm{rc}}=2 \mathrm{MHz}$ で赤血球の緩和周波数は現れず, $f$ が増加するにつ れて，急激に $\varepsilon$ ”が減少することが分かる. 図 5 において， $H$ が増加するごとに $\varepsilon$ ，および， $\rho$ が増加した理由と

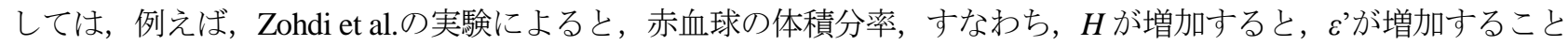
が示されている(Zohdi, et al., 2010). また, Sandberg et al.の実験によると, $H$ が増加すると, $\rho$ が指数関数的に増 加することが示されている(Sandberg, et al., 1981). このことから, $H$ の増加に対する $\varepsilon^{\prime}$ 増加は, $H$ が増加するこ とで，赤血球膜キャパシタンスが増加したためであると考えられる．また， $\rho$ の増加は，赤血球が増加したため に，赤血球の内部抵抗を示寸へモグロビンの量が全体として増加したためであると考えられる.

\section{$4 \cdot 2$ 全血およびヘマトクリットをパラメータとした血栓形成過程と非凝固状態の考察}

図 11 の非凝固状態の結果から, 図 7, および, 図 9 の結果において, $f_{\mathrm{m}}=250 \mathrm{kHz}$ で相対比誘電率 $\varepsilon^{2} *$ の時間変化

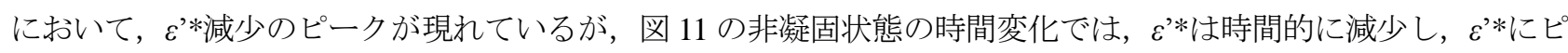
一クは現れず，血栓形成過程と非凝固状態における $\varepsilon * の$ 時間変化は大きく異なる.このことから，ウシ全血の血

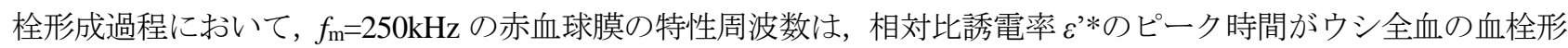

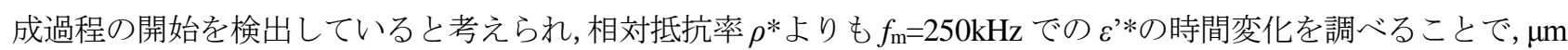
サイズ血栓の形成を検出できると考えられる.

図 12 のへマトクリットをパラメータとした血栓形成過程の結果から, $f_{\mathrm{m}}=250 \mathrm{kHz}$ で, 血栓形成過程における $\varepsilon^{\prime *}$ に減少のピークが現れ，その後，増加に転じる現象は，血栓形成過程，および，赤血球の存在下にのみ発生する 現象であることが明らかとなった。これは， $f_{\mathrm{m}}=250 \mathrm{kHz}$ の $H=0 \%$ 血栓形成過程においてフィブリンが析出して も $\varepsilon^{\prime *} *$ は時間的に減少していることから,$H=10 \%$ 以上の血栓形成過程における $\varepsilon^{* *}$ 増加は, フィブリンの析出に よるものではないことが分かる. したがって, $H=10 \%$ 以上の $\varepsilon^{\prime *}$ 増加は, フィブリンが析出し, 析出したフィ ブリンに赤血球が付着し，赤血球どうしが凝集したことによる反応ではないかと考えられる．また，Hが増加す るごとに減少のピーク時間 $t_{\mathrm{p}}$ が減少した理由としては， $H$ が増加すると，フィブリンの析出後，より早く赤血球 が凝集している, 寸なわち, 赤血球の凝集速度が増加しているのではないかと考えられる.

ここで, 本研究では, ヘマトクリットをパラメータとして血栓形成過程の電気特性量の差異を論じる上での制 約条件として，赤血球の凝集が関わること，および，静止状態において計測が行われることであり，今後は，体 外模擬流路を用いた動的状態における血栓形成過程の電気特性量の時間変化についても評価していく予定である. 


\section{5. 結}

誘電緩和法を用いて，交流測定周波数 $f$ を $1 \mathrm{kHz}$ から $5 \mathrm{MHz}$ まで掃引し，ヘマトクリット $H$ を变化させて比誘 電率 $\varepsilon$ '誘電損失 $\varepsilon$ ”を求め, さらにウシ全血を用いた血栓形成過程，および， $H$ をパラメータとした血栓形成過 程の $\varepsilon$ と抵抗率 $\rho$ を求めた結果, 以下のことが明らかとなった.

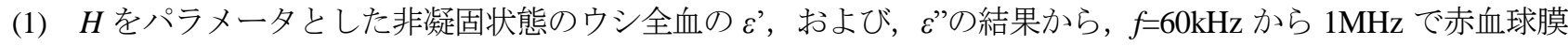
の特性周波数 $f_{\mathrm{m}}, f=2 \mathrm{MHz}$ で赤血球の緩和周波数 $f_{\mathrm{rc}}$ が現れ, $H$ が増加すると $f_{\mathrm{m}}$ での $\varepsilon^{\prime}$ は次関数的に増加す る.

(2) ウシ全血の血栓形成過程において， $f_{\mathrm{ec}}$ ，および， $f_{\mathrm{rc}}$ では相対比誘電率 $\varepsilon^{*} *$ 時間経過につれて減少したが， $f_{\mathrm{m}}$

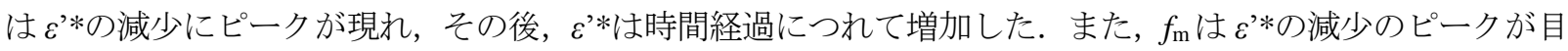
視による $\mu \mathrm{m}$ サイズ血栓形成の時間と一致した.

(3) $f_{\mathrm{m}}$ を用いて $H$ をパラメータとした血栓形成過程において， $H=10 \%$ 以上では， $\varepsilon^{*}$ をの減少にピークが現れたが

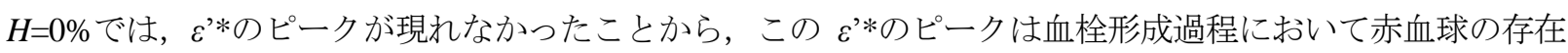
下にのみ起きる挙動である.

以上の本手法の実験結果から,ヘマトクリットをパラメータとした静止血液中の赤血球の特性周波数, および, 血栓形成過程において, ヘマトクリットが相対比誘電率 $\varepsilon$ * 後は, 体外模擬流路を用いて, 誘電緩和法による $\varepsilon^{\prime} * \sigma$ 時間変化を計測することにより, 動的状態におけるリアル タイム血栓検出の可能性について検討する.

\section{謝辞}

本研究の一部は，千葉大学ベンチャービジネスラボラトリー研究費，千葉大学 COE スタートアッププログラ ム研究費，および，(一社) 日本人工臓器学会平成 24 年度 Yoshimi T.M.P Grantによってなされました. 本実験を行 うにあたり，千葉大学大学院工学研究科博士前期課程 1 年の布施拓士君にご協力いただきました。また，本実験 における電気計測において，アジレント・テクノロジー・インターナショナル(株)の烏川浩明氏にご助言をいた だきました。ここに厚く御礼申し上げます.

\section{文献}

Affani, A., Specogna, R. and Trevisan, F., Electrical impedance spectroscopy on flowing blood to predict white thrombus formation in artificial micro-channels, International Instrumentation and Measurement Technology Conference Proceedings (2012), pp.1477-1480.

朝倉悠太，サプコタアチュタ，丸山修，小阪亮，山根隆志，武居昌宏，プロセス・トモグラフィー法による静止血液 中の沈降血栓の時間空間可視化計測，可視化情報学会論文集, Vol.33, No.10 (2013), pp.17-24.

Asami, K., Characterization of biological cells by dielectric spectroscopy, Journal of Non-Crystaline Solids, Vol.305, No.3-5 (2002), pp.268-277.

福島克也, 玉川雅章, 平本美記, せん断流れ場における血栓形成の可視化, 生体医工学, Vol.45, No.1 (2007), pp.99-105.

花井哲也, 不均質構造と誘電率 (2000), pp.61-78, 吉岡書店.

Hayashi, Y., Katsumoto, Y., Omori, S., Yasuda, A., Asami, K., Kaibara, M. and Uchimura, I., Dielectric coagulometry: A new approach to estimate venous thrombosis risk, Analytical Chemistry, Vol.82, No.23 (2010), pp.9769-9774.

Lisbeth, E., Verena, T., Georg, H., Ludwig, T., Paul, A. K. and Sabine, E., Hematocrit and the Risk of Recurrent Venous Thrombosis: A Prospective Cohort Study, PLoS ONE, Vol.7, No.6 (2012), e38705.

Noshiro, M., Nebuya, S., Fujimaki, A., Smallwood, R. and Brown, H. B., Frequency characteristics of the electrical conductivity in normal and coagulated blood, International Federation for Medical and Biological Engineering Proceedings, Vol.17 (2007), pp.70-72.

Oshima, S. and Sankai, Y., Improvement of the accuracy in the optical hematocrit measurement by optimizing mean optical path length, Artificial Organs, Vol.33, No.9 (2009), pp.749-756.

Park, H. J., Kim, S. C., Choi, C. B. and Ham, Y. k., The correlation of the complex dielectric constant and blood glucose at 
low frequency, Biosensors and Bioelectronics, Vol.19, No.4 (2003), pp.321-324.

Sandberg, K., Sjoqvist, A. B. and Olsson, T., Relation between blood resistivity and hematocrit in fresh human fetal blood, Pediatric Research, Vol.15 (1981), pp.964-966.

佐々木栄作, 中谷武嗣, 妙中義之, 穴井博文, 広瀬一, 高野久輝, 電気インピーダンス測定による人工臟器内血液 量のリアルタイム計測, 人工臟器, Vol.21, No.2 (1992), pp.484-488.

Tamagawa, M., Kaneda, H., Hiramoto, M. and Nagahama, S., Simulation of thrombus formation in shear flows using Lattice Boltzman method, Artificial Organs, Vol.33, No.8 (2009), pp.604-610.

山本尚武, 中村隆夫, 生体電気計測 (2011), pp.11-18, コロナ社.

Yamane, T., The present and future state of non-pulsatile artificial heart technology, Journal of Artificial Organs, Vol.5, No.3 (2000), pp.149-155.

Zohdi, I. H., Kuypers, A. F. and Lee, C. W., Estimation of red blood cell volume fraction from overall permittivity measurements, International Journal of Engineering Science, Vol.48, No.11 (2010), pp.1681-1691.

\section{References}

Affani, A., Specogna, R. and Trevisan, F., Electrical impedance spectroscopy on flowing blood to predict white thrombus formation in artificial micro-channels, International Instrumentation and Measurement Technology Conference Proceedings (2012), pp.1477-1480.

Asakura, Y., Sapkota, A., Maruyama, O., Kosaka, R., Yamane, T. and Takei, M., Spatio-temporal measurement of sedimenting thrombus in static blood using process tomography, Transactions of Visualization Society of Japan, Vol.33, No.10 (2013), pp.17-24 (in Japanese).

Asami, K., Characterization of biological cells by dielectric spectroscopy, Journal of Non-Crystaline Solids, Vol.305, No.3-5 (2002), pp.268-277.

Fukushima, K., Tamakawa, M. and Hiramoto, M., Visualization of thrombus formation process and flow analysis on shear blood flow, Transactions of Japanese Society for Medical and Biological Engineering, Vol.45, No.1 (2007), pp.99-105 (in Japanese).

Hanai, T., Fukinshitsukouzou to Yudenritsu, Yoshioka Shoten (2000), pp.61-78 (in Japanese).

Hayashi, Y., Katsumoto, Y., Omori, S., Yasuda, A., Asami, K., Kaibara, M. and Uchimura, I., Dielectric coagulometry: A new approach to estimate venous thrombosis risk, Analytical Chemistry, Vol.82, No.23 (2010), pp.9769-9774.

Lisbeth, E., Verena, T., Georg, H., Ludwig, T., Paul, A. K. and Sabine, E., Hematocrit and the Risk of Recurrent Venous Thrombosis: A Prospective Cohort Study, PLoS ONE, Vol.7, No.6 (2012), e38705.

Noshiro, M., Nebuya, S., Fujimaki, A., Smallwood, R. and Brown, H. B., Frequency characteristics of the electrical conductivity in normal and coagulated blood, International Federation for Medical and Biological Engineering Proceedings, Vol.17 (2007), pp.70-72.

Oshima, S. and Sankai, Y., Improvement of the accuracy in the optical hematocrit measurement by optimizing mean optical path length, Artificial Organs, Vol.33, No.9 (2009), pp.749-756.

Park, H. J., Kim, S. C., Choi, C. B. and Ham, Y. k., The correlation of the complex dielectric constant and blood glucose at low frequency, Biosensors and Bioelectronics, Vol.19, No.4 (2003), pp.321-324.

Sandberg, K., Sjoqvist, A. B. and Olsson, T., Relation between blood resistivity and hematocrit in fresh human fetal blood, Pediatric Research, Vol.15 (1981), pp.964-966.

Sasaki, E., Nakatani, T., Taenaka, Y., Anai, H., Hirose, H. and Takano, H., Real time measurement of blood volume in artificial heart using electrical impedance, Journal of Artificial Organs, Vol.21, No.2 (1992), pp.484-488 (in Japanese).

Tamagawa, M., Kaneda, H., Hiramoto, M. and Nagahama, S., Simulation of thrombus formation in shear flows using Lattice Boltzman method, Artificial Organs, Vol.33, No.8 (2009), pp.604-610.

Yamamoto, N. and Nakamura, T., Seitai Denki Keisoku, Corona Publishing Co. Ltd. (2011), pp.11-18 (in Japanese).

Yamane, T., The present and future state of non-pulsatile artificial heart technology, Journal of Artificial Organs, Vol.5, No.3 (2000), pp.149-155.

Zohdi, I. H., Kuypers, A. F. and Lee, C. W., Estimation of red blood cell volume fraction from overall permittivity measurements, International Journal of Engineering Science, Vol.48, No.11 (2010), pp.1681-1691. 